\title{
Credit Ratings as Coordination Mechanisms
}

\author{
By: Arnoud W. A. Boot and Todd T. Milbourn
}

William Davidson Working Paper Number 457

March 2002 


\title{
Credit Ratings as Coordination Mechanisms*
}

\author{
Arnoud W. A. Boot ${ }^{\dagger}$ \\ Todd T. Milbourn $\ddagger$
}

March 15, 2002

\footnotetext{
*Acknowledgements: We thank Mike Burkhart, Mark Carey, Erik Durbin, Denis Gromb, Manju Puri, Anjan Thakor, and seminar participants at the IMF, WorldBank, and Stockholm School of Economics for fruitful discussions and comments. Any remaining errors are our own.

${ }^{\dagger}$ Faculty of Economics and Econometrics, University of Amsterdam, Roetersstraat 11, 1018 WB Amsterdam, The Netherlands, Tel: +3120525 4162 Fax: +31205255285 email: awaboot@fee.uva.nl

${ }^{\ddagger}$ Washington University in St. Louis, John M. Olin School of Business, Campus Box 1133, 1 Brookings Drive, St. Louis, MO 63130-4899 Tel: 314-935-6392 Fax 314-935-6359 e-mail: milbourn@olin.wustl.edu website: http://www.olin.wustl.edu/faculty/milbourn/
} 


\title{
Credit Ratings as Coordination Mechanisms
}

\begin{abstract}
In this paper, we provide a novel rationale for credit ratings. The rationale that we propose is that credit ratings can serve as a coordinating mechanism in situations where multiple equilibria can obtain. We show that credit ratings provide a "focal point" for firms and their investors. We explore the vital, but previously overlooked implicit contractual relationship between a credit rating agency and a firm. Credit ratings can help fix the desired equilibrium and as such play an economically meaningful role. Our model provides several empirical predictions and insights regarding the expected price impact of ratings changes, the discreteness in funding cost changes, and the effect of the focus of organizations on the efficacy of credit ratings.
\end{abstract}




\section{Introduction}

Credit ratings are quite prevalent in financial markets. Most corporate bond issues have at least one rating, many have two. In fact, the two most prominent ratings agencies - Moody's and Standard \& Poor's - adhere to a policy of providing a rating for all taxable corporate bonds publicly issued in the U.S. For many observers of the financial market, credit ratings appear to have real importance, that is, the common perception is that lower ratings lead to higher funding costs, and vice versa. However, the financial economics literature has cast doubt on the importance of announced changes in these ratings. A common argument is that the rating change may actually go hand in hand with, or even more likely follow an informational release and thus may have by itself no informational content.

The empirical evidence surrounding credit ratings is far from conclusive. In fact, most empirical studies provide mixed results for the effects of rating changes on stock prices. ${ }^{1}$ In our view this is not surprising. What is missing from the literature is an understanding of the way ratings come about and the role credit ratings actually play in the financial markets. From this perspective, we will show that credit ratings play an economically meaningful role, confirming their increasingly important role in practice. $^{2}$

Academics have previously examined credit ratings from an informational content/market efficiency point of view. We believe that credit ratings derive their value much more from two institutional features. What we show is that credit ratings can serve as "focal points". By this we mean that credit ratings help fix the desired equilibrium in environments for which multiple equilibria would otherwise exist. The first key to our theory is the ongoing monitoring role of credit rating agencies through their credit watch procedures. This is a previously much overlooked feature of credit rating agencies. Their job is not just the initial information dissemination, but also the ongoing monitoring aspect through credit watch procedures. Here implicit contracts play an important role. In particular, a credit rating agency will interact with the firm that it rates,

\footnotetext{
${ }^{1}$ In Section 4.1, we discuss the extant empirical evidence.

${ }^{2}$ Another illustration of the increased importance of credit ratings is the proliferation of credit risk models. See Nickell, Perraudin, Varotto (1999), Carey and Hrycay (2000), and Saunders (1999) for some interesting work on this issue.
} 
and write implicit contracts with management once potential changes in firm characteristics and/or market circumstances threaten to affect its credit rating. The credit rating procedure allows for a "deal" (implicit contract) between the firm and credit rating agency where the former promises to undertake specific actions to mitigate the possible deterioration of its credit standing (and rating). We show that the credit rating and associated implicit contract is incentive compatible provided that a group of (institutional) investors conditions its decisions on the rating. The latter is the second institutional feature that is important for our theory.

There is ample evidence on the presence of our second institutional feature. Pension fund guidelines often stipulate that investments are only allowed in highly-rated issues (e.g., those of investment grade). Dating back to as early as 1936, government regulations in the U.S. have prohibited various types of financial institutions from holding speculative-grade bonds. ${ }^{3}$ Similarly, specific markets, such as the Eurobond market, may simply require the presence of a rating before listing the debt issue. These rigidities effectively condition the investors' decisions on the observed rating. ${ }^{4}$

In the setting that we analyze, we let firms that are in need of debt financing interact with the financial market. The market cannot readily observe the quality of the firms' investment opportunities. This may induce moral hazard. We show that depending on the beliefs of the market, the firm might be induced to choose high-risk or low-risk strategies. For instance, if the market anticipates a risky project choice, it will demand a high coupon rate in the debt contract. However, this belief may well be self-fulfilling: once the firm is confronted with the high funding cost, it will optimally engage in the risky project. Alternatively, the firm might be induced to choose the low-risk strategy if that is what the market anticipates. Thus, multiple equilibria may be present, and depending on which project is first best, the equilibrium might be dissipative.

\footnotetext{
${ }^{3}$ Cantor and Packer (1997) provide a select list of ratings-based U.S. regulations. For instance, the Congressional promulgation of the Financial Institution Recovery and Reform Act of 1989 prohibited Savings \& Loans from investing in below-investment-grade bonds. Imposing a higher ratings bar, the SEC amendment to Rule 2a-7 under the Investment Company Act of 1940 required money market mutual funds to limit holdings of low-rated bonds, where the minimum rating imposed was $\mathrm{A}+(\mathrm{A} 1)$.

${ }^{4}$ Other examples of links between investor behavior and credit ratings are clauses that link particular decisions to credit ratings. For example, in the case of Enron, the proposed takeover of Dynergy was made contingent on having an investment grade rating. Moreover, some of Enron's partnerships required accelerated debt repayments if stock prices declined significantly and a credit rating downgrade to non-investment (speculative) grade status occurred (International Herald Tribune (2002)).
} 
What we show in our model is that if a sizable proportion of investors (e.g., pension funds) follows the credit rating (i.e., bases their investment decisions on the credit rating because of institutional rigidities), others rationally follow as well. This can resolve the multiple equilibria problem and points at the focal point role of credit ratings that we develop in this paper.

Our work incorporates some other insights that are brought forward by practice. Practitioners often claim that credit ratings are deemed essential to access a wider group of investors. Dallas (1997) argues that,

Among the key benefits, ratings often provide the issuers with an 'entry' ticket in public debt markets, broadening the issuers' financing opportunities.

Issuing bonds to a specific group of investors or floating them on a particular market may only be feasible if a credit rating is present. For example, ratings may help in disseminating information to relatively uninformed investors. Rating agencies could be seen as information-processing agencies that may speed up the dissemination of information to financial markets. As put forward by Moody's, a prominent rating agency:

The ratings are intended to provide investors with an independent, forward-looking assessment of long-term credit risk according to a globally comparable standard. ${ }^{5}$

Thus, ratings would act as 'information equalizer', thereby enlarging the investor base. Much of the literature on credit ratings focuses on how, as independent information producers, credit rating agencies can help disseminate information about firms to investors.

In our theory, credit ratings have a role as 'information equalizer', albeit a more subtle one. In particular, we will argue that ratings really serve as a focal point in that in the end all investors may rationally base their investment and pricing decisions on the rating, anticipating that sufficiently many will do so. As discussed, institutional rigidities (such as restrictions to hold only investment grade securities) could make such an equilibrium robust.

The role that credit ratings play in our story has links to the literature on "cheap talk", such as Spatt and Srivastava (1991) and Morris (1999). The argument is that a credit rating in the "focal

\footnotetext{
${ }^{5}$ See McDaniel (1997).
} 
point" interpretation only has value because some investors choose to take the announced rating seriously. In doing so, they affect the funding cost and consequently the behavior of the firm, which in turn confirms the rating. If we are right, and we do believe that the coordination of beliefs function of ratings is quite significant, ratings may have little informational content but actually be insurance policies against a bad equilibrium. ${ }^{6}$ This is consistent with the mixed empirical evidence.

The rest of the paper is organized as follows. Section 2 describes the model and contains the basic equilibrium analysis. Section 3 examines credit ratings as a resolution to multiple equilibria. In Section 4, we extract several empirical predictions and discuss existing empirical evidence. Section 5 extracts other implications of the analysis, and Section 6 concludes. All proofs are in the Appendix.

\section{Model Setup}

We model an economy in which there are firms of varying quality seeking debt financing from investors. We assume a perfectly competitive financial market. The investment opportunity sets vary across firm type, where firms are either of good $(\mathrm{G})$ quality or they are lemons $(\mathrm{L})$. The prior probability that a given firm is good is $\beta \in[0,1]$, and we refer to this $\beta$ as "market quality". We assume universal risk neutrality and a risk-free rate of zero.

\section{$2.1 \quad$ Projects}

Each type of firm has access to at least one type of project. All projects require an investment of $I>0$, and neither firm has any resources available to invest in the project. Instead, firms must raise $I$ in debt from investors. We allow good firms access to two types of projects, a safe one $(\mathrm{S})$ and a risky one $(\mathrm{R})$. A safe project is risk free and pays off a positive amount $X_{S}$ with probability 1 . The risky project pays off a positive amount $X_{R}>X_{S}$ with probability $\gamma$, and zero

\footnotetext{
${ }^{6}$ Our focal point interpretation has some similarities to Dow and Rossiensky (1999). They build a model of a financial firm that finances itself by issuing risky debt. Financial firms raise money first, and then choose which assets to hold. Thus, liability structure and investment policy are inextricably linked in that a liability structure is chosen in anticipation of particular investment opportunities. However, after funds are raised, if the investment opportunity set has changed, the finance company is left with a suboptimal asset-liability mix which could induce multiple equilibria problems. We identify situations in which multiple equilibria might arise as well, but our focus is on how these can be resolved by credit ratings.
} 
with probability $1-\gamma$. We assume that the first-best project choice is the safe one in that the expected value of the safe project exceeds that of the risky project $\left(\gamma X_{R}<X_{S}\right)$. Lemon firms have access to only the risky $(\mathrm{R})$ project. We assume that both projects have a positive NPV in that $X_{S}>\gamma X_{R}>I$.

\subsection{Information Structure, Funding Costs and Equilibrium Behavior}

The information structure is such that investors cannot contract on the firm's project choice as this is privately known to the firm. Moreover, project payoffs are unobservable. With this structure, it can be shown from the work of Townsend (1979), Diamond (1984) and Gale and Hellwig (1985) that debt is the optimal contract. ${ }^{7}$ Thus, firms in our model approach the market for debt financing. Each loan consists of an amount lent $(I)$ to fund the investment. The loan also dictates the repayment amount due, which we denote $F^{\tau}$, where $\tau \in\{S, R\}$ represents the market's conjecture of the good firm's project choice. The lemon firm only has access to the risky $(R)$ project.

The information structure is such that the market cannot distinguish good firms from lemons. The cross-sectional distribution of $\operatorname{good}$ borrowers $(\beta)$ and lemons $(1-\beta)$ is public information. Thus, the repayment amount $\left(F^{\tau}\right)$ may depend on the belief $(\beta)$ over the type of the borrowing firm and the conjectured project choice of the good firm. Since the financial market is competitive, investors are risk neutral and the riskless discount rate is zero, the expected repayment - with expectations taken over the cross-sectional distribution of good borrowers $(\beta)$ and lemons $(1-\beta)-$ on any loan in equilibrium will be equal to the amount lent. That is, $E\left[F^{\tau}\right]=I$, for all $\tau \in\{S, R\}$ and $\beta \in[0,1]$. Lemma 1 gives the repayment amounts required by investors.

\section{Lemma 1}

Investors condition the terms of the loans they offer based on the conjecture of a good firm's project choice. If investors anticipate that a good firm will choose the safe project, they require a

\footnotetext{
${ }^{7}$ See Diamond (1992) for a fuller discussion of the optimality of debt contracts in such a setting.
} 
repayment amount of

$$
F^{S}=\frac{I}{\beta+[1-\beta] \gamma}
$$

Alternatively, if the investors anticipate that a good firm will choose the risky project, they require a repayment of

$$
F^{R}=\frac{I}{\gamma}
$$

where repayment amount $F^{R}>F^{S}$.

The results of Lemma 1 are straightforward. The investment behavior of the good firm has an important effect on financing costs. ${ }^{8}$ The required repayment is higher if the market anticipates that a good firm will choose the risky project over the safe alternative. Moreover, since firm type is unobservable by the market, the required debt repayment when the safe project choice is anticipated by investors depends on the prior belief $(\beta)$ that the firm is good. This is not the case when the risky project choice is anticipated as the good firm and the lemon earn identical expected payoffs in this case. Thus, as the prior belief that the firm is good increases, the financing cost it faces when investors anticipate the safe project choice strictly declines, but the risky project choice repayment is unaffected.

Given the funding costs derived in Lemma 1, the good firm's equilibrium choices are delineated in Theorem 1.

\section{Theorem 1}

The good firm's project choices in the set of plausible Bayesian Perfect Nash Equilibria are: ${ }^{9}$

1. If the prior belief over firm quality is sufficiently low such that $\beta<\underline{\beta}$, the good firm will choose the risky project regardless of the market's beliefs about its anticipated project choice.

2. If the prior belief over firm quality is sufficiently high such that $\beta \geq \underline{\beta}$, the good firm will choose whichever project the market anticipates will be taken. Thus, if the market anticipates

\footnotetext{
${ }^{8}$ Recall that lemons have only one project choice; they always choose the risky (R) project.

${ }^{9}$ Depending on the parameters in the model, either of these two regions could be empty.
} 
the safe choice, the good firm optimally chooses the safe project. However, if the market anticipates the risky project, it is then optimal for the good firm to choose the risky project in equilibrium. Hence, there are multiple equilibria in this intermediate $\beta$ range.

The results of Theorem 1 show that a good firm's investment choice in equilibrium depends on the market's prior beliefs on the investment choice for a market of sufficiently high quality $(\beta \geq \underline{\beta})$. If the quality of the market is low $(\beta<\underline{\beta})$, investor beliefs about the good firm's project choice are unimportant. Here, the lemon problem is so severe that a good firm will always engage in asset-substitution moral hazard. That is, the risky project will be chosen even if the market would anticipate the safe choice. The reason is that the presence of lemons inflates the repayment obligation such that the good firm has no incentive to invest in the safe project in equilibrium.

Theorem 1 shows that when the quality of the market is sufficiently high $(\beta \geq \underline{\beta})$, multiple equilibria are possible as investor beliefs over the good firm's project choice are paramount in determining which equilibrium obtains. Within this region, it is optimal for the good firm to choose the project that is anticipated by the market. Thus, even though the safe project is the first best and is a feasible outcome in this region of market quality, investor beliefs can drive the firm to the undesirable equilibrium where the risky project is chosen. In the remainder of the paper, we focus on this region where multiple equilibria are possible and seek out resolutions to this problem.

\subsection{Resolving the Multiple Equilibria Problem}

In this subsection, we show that if there exists a sufficiently sizeable subset of investors that believes good firms will choose the safe project, the remaining investors will also rationally conjecture that the safe project will be chosen. In Section 3, we analyze how credit ratings could facilitate such "coordination" among investors.

The more fundamental issue is what does the investors' behavior imply for the firms for which multiple equilibria exist? As derived in Theorem 1 , for the region $\beta \geq \underline{\beta}$, good firms optimally choose whichever project the market anticipates. However, this result can be generalized. If a 
sufficiently sizeable subset of investors anticipates the safe project to be chosen, good firms will in fact find it in their own best interests to choose the safe project, and vice versa.

This observation can be modelled as follows. Let $\alpha \in[0,1]$ be the proportion of investors that anticipates that a particular good firm always chooses the safe project. ${ }^{10}$ The remaining $1-\alpha$ proportion of investors simply form their own beliefs over the good firm's project choice, but is aware of the presence of the $\alpha$ investors. What we will show is that if the proportion of investors "playing" the safe equilibrium $(\alpha)$ is sufficiently big, the good firm always picks the safe project regardless of the conjectures of the remaining $1-\alpha$ investors.

Observe that with two different investor classes, we can envision the firms auctioning off the debt claim in two tranches. The proportion $\alpha$ of (institutional) investors anticipates the safe project. This implies that the price of this debt claim is such that $F^{S}=\frac{I}{\beta+[1-\beta] \gamma}($ see $(1))$. If the $1-\alpha$ investors anticipate that the risky project will be chosen, they require a higher repayment value, i.e., $F^{R}=\frac{I}{\gamma}$ (see (2)). The total repayment obligation faced by a good firm is therefore given by

$$
F^{\alpha}=\alpha F^{S}+[1-\alpha] F^{R}
$$

It is obvious that for any $\alpha \in(0,1), F^{\alpha} \in\left(F^{S}, F^{R}\right)$, and that this weighted-average debt-repayment amount is decreasing in the fraction of investors, $\alpha$, anticipating the safe project choice $\left(\frac{\partial F^{\alpha}}{\partial \alpha}<0\right)$. Thus, the total funding costs decline as the proportion $\alpha$ increases.

Facing such financing costs, the good firm compares its net expected benefit from choosing the safe project to that of the risky project. If it chooses the risky project (as the $1-\alpha$ investors anticipate), it receives in expectation

$$
\left[\begin{array}{c}
\operatorname{Pr}(\text { Risky Project Succeeds }) \times\left[X_{R}-F^{\alpha}\right] \\
+\operatorname{Pr}(\text { Risky Project Fails }) \times[0]
\end{array}\right]=\gamma\left[X_{R}-F^{\alpha}\right] .
$$

While if it chooses the safe project, which is risk free, it receives

$$
X_{S}-F^{\alpha}
$$

\footnotetext{
${ }^{10}$ In the next section, we address what could explain why a particular set of investors might play only the good equilibrium.
} 
The critical proportion $\alpha^{*}$ equates (4) and (5). We can now proceed to our result that formalizes the impact of the proportion $\alpha$ of investors on the equilibrium.

\section{Theorem 2}

For every quality of the market $\beta \geq \underline{\beta}$, there exists a critical proportion $\alpha^{*}$ of investors that believe the safe project will be chosen such that for $\alpha>\alpha^{*}$, the good firm will always choose the safe project. In these cases, the remaining $1-\alpha$ investors also rationally assume that the good firm chooses the safe project. Hence, financing costs are given by $F^{S}$ whenever $\alpha>\alpha^{*}$.

What this theorem states is that a significant proportion of investors playing the safe equilibrium can actually guide firm behavior to the desired (first-best) risk choice. The remaining proportion $(1-\alpha)$ of investors should then rationally anticipate the safe project choice as well. The intuition for this result is as follows. Investors who anticipate that the good firm will play the safe equilibrium will price the debt repayment commensurately. And while there are other investors who may anticipate that the risky project will be taken, total funding costs are reduced as the proportion

of investors playing the safe equilibrium $(\alpha)$ increases (i.e., $\frac{\partial F^{\alpha}}{\partial \alpha}<0$ ). The critical proportion of investors playing the safe equilibrium $\left(\alpha^{*}\right)$ is simply the proportion of investors that equates the good firm's expected benefits from investing in the safe and the risky project, respectively, anticipating that the others $(1-\alpha)$ will anticipate the risky project choice. At any proportion of such investors above this threshold, the good firm will always play the safe equilibrium. The beliefs of these $\alpha$ investors are then fully confirmed in equilibrium, and the remaining $1-\alpha$ investors now rationally conjecture the good firm's behavior as well. Thus, with both sets of investors anticipating the safe project choice, total funding costs drop to $F^{S}$, for all $\alpha>\alpha^{*}$.

The prior over firm quality $(\beta)$ plays a key role in the formation of this critical proportion $\alpha^{*}$ of investors. 


\section{Corollary to Theorem 2}

The critical proportion of investors, $\alpha^{*}$, such that the good firm will always choose the safe project whenever $\alpha>\alpha^{*}$, is decreasing in the prior over firm quality ( $\beta$ ).

This Corollary to Theorem 2 states that the minimum proportion of investors playing the safe equilibrium $\left(\alpha^{*}\right)$ that is necessary to insure the selection of the safe project, is strictly decreasing in the prior over firm quality, $\beta$. The intuition is similar to that of Theorem 2. As the prior that the firm is good increases, the total funding costs $\left(F^{\alpha}\right)$ decline. Since the favorable effect of an improving prior (higher $\beta$ ) is only relevant if the safe project is chosen, the critical proportion of investors $\alpha^{*}$ decreases. Intuitively, at higher levels of market quality (i.e., average quality of firms $(\beta)$ is higher), asset substitution problems (risky project choices) are smaller. Hence, a lower threshold $\alpha^{*}$ resolves these problems.

\section{Credit Ratings as a Resolution to Multiple Equilibria}

In this section, we establish what we see as the key role of credit ratings. Central to our theory is that credit ratings help mitigate the multiple equilibria problem in that the credit ratings serve as focal points. In our model formulation, this is relevant for the range of firm qualities where multiple equilibria are possible $(\beta \geq \underline{\beta})$. As emphasized in the Introduction, a key element to our theory is that institutional rigidities link the actions of some investors to the observed credit ratings and other investors are aware of the institutional rigidities that some face. The institutional rigidity we model is that a nonzero proportion of investors acts on the basis of the announced credit rating. For example, institutional investors make up a sizeable portion of the debt market, but are often restricted to invest in only highly-rated firms. Thus, we let the proportion of investors represented by institutions be given by $\alpha$. Their investment behavior is therefore (partially) driven by the announced ratings. 


\subsection{Interactions Between CRA and the Firm}

The immediate question underlying our premise is why some investors - i.e., the institutional investors - are ever willing to base their investment decisions on the rating? That is, what makes the credit rating credible?

Recall that the rating as such has no informational content. While it could identify the "good" equilibrium, the possibility of such an equilibrium was already known to the market. Here it is crucial to consider the role a credit rating agency plays in practice, and in particular the credit watch procedure. What has previously been ignored is that a CRA does have regular interactions with firms, and engages in implicit contracting with the firm. How does this work? Whenever the CRA observes potential changes in firm characteristics, they will notify management and ask for clarification. The rating is then often put "on watch". The firm will generally be asked to provide information on how it is going to deal with the "change". The CRA and firm can strike "a deal" where the firm promises to undertake specific actions to mitigate the possibly adverse consequences of the change. For this, concrete targets with associated deadlines are often set. During this period the rating continues to be "on watch". If the firm manages to live up to this implicit contract, the rating may get reconfirmed. If not, a downgrade could occur.

A recent example of the dialogue that takes place between CRAs and firms can be found in the European telecommunications industry. ${ }^{11}$ Credit rating downgrades were suffered by four prominent firms, including British Telecom, France Telecom, Deutsche Telekom, and KPN. These downgrades came on the heels of several exchanges between various CRAs and these firms, as seen by the following quote: "Last September, Moody's downgraded companies including KPN and France Telecom and said it would give them 12-18 months to reduce their debt in line with their new ratings." Table 1 summarizes the recent history for two other players in this industry.

\footnotetext{
${ }^{11}$ See Alice van Duyn and Rebecca Bream, "Credit Rating Agencies Show Their Teeth", Financial Times, February 27,2001 , page 28 .
} 


\section{Table 1: Credit Rating Changes in the Telecommunications Industry}

\begin{tabular}{|c|c|c|}
\hline & \multicolumn{2}{|c|}{ Credit Rating Agency } \\
\hline Firm/Date & $\mathbf{S} \& \mathbf{P}$ & Moody's \\
\hline \multicolumn{3}{|c|}{ British Telecom } \\
\hline Feb 2000 & AA plus & Aa1 \\
\hline Apr 242000 & Put on negative watch & - \\
\hline May 42000 & - & Put on negative watch \\
\hline Aug 242000 & Cut to $\mathrm{A}$ & - \\
\hline Sep 62000 & - & Cut to A2 \\
\hline Feb 162001 & Put on negative watch & - \\
\hline \multicolumn{3}{|c|}{ Deutsche Telekom } \\
\hline Feb 2000 & AA minus & Aa2 \\
\hline Apr 262000 & Put on negative watch & - \\
\hline Jun 222000 & - & Put on negative watch \\
\hline Oct 52000 & - & Cut to A2 \\
\hline Oct 62000 & Cut to A minus* & - \\
\hline
\end{tabular}

The existing credit ratings literature has ignored this interaction between the CRA and the firm, and therefore overlooked the "control" that the CRA has over the behavior of the firm. Strictly speaking, the actual control comes from the investors that base their investment and pricing decisions on the credit rating, and in doing so make the implicit contract between the CRA and firm incentive compatible. For market participants, this implies that a credit rating has a potentially valuable contractual feature, even in the absence of an informational advantage. The examples in Table 1 all point at a "negative watch" qualification. This is typical for the implicit contracts upon which we focus. Credit rating agencies typically contract with firms on preventing downgrades. Not surprisingly then, our theory predicts that (ultimate) downgrades are negative news and have a negative stock market impact, while upgrades may not have a stock 
market impact. The following analysis formulates the process by which credit ratings can serve as an incentive-compatible, coordination mechanism.

\subsection{Credit Ratings in Equilibrium}

We assume the existence of a credit rating agency (CRA) that assigns a credit rating $\left(c \in\left\{c_{R}, c_{S}\right\}\right)$ to the debt claim a firm is trying to sell to the market. The rating can designate that the issuing firm will engage in the risky project $\left(c=c_{R}\right)$ or the safe project $\left(c=c_{S}\right)$. Since the CRA is not screening firms in our model, the lemons continue to affect the borrowing cost $F^{S}$ of the good firms. The presence of lemons in the marketplace effectively adds noise and increases the funding cost regardless of the credit rating assigned by the CRA. Thus, the CRA's assigned credit rating is not based on private information, but is based on a promise by the firm to choose the designated risks. In addition, institutional investors $(\alpha)$ are restricted to investing in debt issues for which the safe credit rating is assigned. In what follows, we examine what happens when the CRA assigns these ratings. In Table 2 we have summarized the sequence of events in the model that now includes the CRA. 


\section{Table 2: Sequence of Events}

$$
\text { At } \mathrm{t}=0
$$

1. Nature moves and firms are either "good" or "lemons" with probabilities $\beta$ and $1-\beta$, respectively

2. Firm needs $\$ I$ to invest in project (good firms have access to safe and risky projects, lemons only have access to risky projects)

3. Debt investors will lend an amount $I$, and ask for a fixed repayment based on their conjecture of the good firm's project choice. Here, the sequence is:

3.1 The CRA announces either $c_{S}$ or $c_{R}$ (safe or risky) rating

3.2 If $c_{S}$ is announced, institutional $\alpha$ investors are allowed to invest and conjecture that good firm will choose safe project. If $c_{R}$ is announced, then $\alpha$ investors abstain from lending

3.3 Remaining $1-\alpha$ investors then form beliefs about firm's investment behavior based on size of $\alpha$

3.4 Investors (including institutional investors only in the case of $c_{S}$ rating) lend $I$ in exchange for a fixed repayment based on their beliefs about investment behavior

4. Firm then chooses project based on repayment schedule offered by investors

$$
\text { At } \mathbf{t}=1
$$

5. Projects pay off; safe projects pay off $X_{S}>0$ for sure, and risky projects pay off $X_{R}>X_{S}$ with probability $\gamma$ (and zero otherwise)

6. Firm repays debt obligation if project payoff is positive, and defaults otherwise

\section{CRA announces Risky Rating}

The case where the CRA announces the risky rating is straightforward. Observe that if $c=c_{R}$, the proportion of institutional investors is $\alpha=0$. These investors can only lend funds if the safe credit rating is assigned to the firm's debt. The non-institutional investors who do not face any investment restrictions now lack guidance. They will simply play either the good or the bad 
equilibrium, the multiple equilibria problem manifests itself again, and the good firm will choose whichever project is anticipated by investors.

\section{CRA announces Safe Rating}

If the CRA announces the safe credit rating $\left(c_{S}\right)$, institutional investors are in the market. These investors condition their investment behavior on the credit rating. Here, the result of Theorem 2 plays a key role. If a sufficient proportion of institutional investors are present, the good firm will optimally choose the safe project. The intuition is analogous to that of Theorem 2. With a sufficiently large proportion of institutional investors (conditioning their pricing on the safe credit rating), the funding cost for the firm is relatively low. This induces the firm to choose the safe project and effectively induces all investors to price according to the announced credit rating. We formulate this in the next result.

\section{Theorem 3}

If the proportion of institutional investors exceeds $\alpha^{*}$ (see Theorem 2), the CRA will engage in implicit contracting with the firm and announce a credit rating $c=c_{S}$. The good firm optimally chooses the safe project, and all investors will condition their investment and pricing decisions on this rating.

What this theorem shows is that credit ratings have a role as an incentive-compatible "coordination mechanism". The mechanics by which this process works is as follows. The CRA fixes firm behavior with its implicit contract, and firms choose to adhere to this implicit contract because it rationally anticipates that investors condition their investment and pricing decisions on the rating, thereby confirming the rating and investor beliefs.

As a final observation, note that we have implicitly assumed that if the CRA can add value, it will do so. The CRA seeks to induce the first-best project-choice, and this is the safe project. While it would be of interest to quantify the potential agency problem with the CRA, it is not the 
focus of our analysis. ${ }^{12}$

\subsection{Impact of Noise and Moral Hazard on Credit Ratings}

The focal point story essentially purports credit ratings as an insurance policy against uncoordinated jumps to the bad equilibrium. When is this most valuable? The value of credit ratings depends on three frictions in the model:

1. the severity of noise, i.e., the mispricing caused by lemons in the model;

2. the moral hazard problem faced by the (good) firm. That is, how easy is it to engage in asset substitution? And

3. how divergent and uncoordinated are the beliefs of investors in the market?

The first two frictions have a straightforward effect, and can be analyzed within the context of our model. The severity of noise (i.e., the lemons problem) is represented by the parameter $\beta$. More lemons (lower $\beta$ ) imply a deterioration of the quality of the market, which dampens the pricing impact of credit ratings. Essentially, noise obscures the role ratings play. The opposite holds for the severity of the moral hazard problem of the good firms. More severe asset-substitution moral hazard (lower $\gamma$ ) increases the funding cost differential between the two credit ratings. The next Corollary summarizes these insights.

\section{Corollary to Theorem 3}

As the noise becomes more severe (i.e., the cross-sectional proportion of lemons $(1-\beta)$ increases), the funding cost differential between the cases when the market anticipates the risky and safe project choices, respectively, strictly decreases. Thus, the differential between the pricing in case of a safe, respectively risky, rating decreases. On the other hand, more severe moral hazard (i.e., lower $\gamma$, thus more risk in the risky project) would increase this differential in pricing. ${ }^{13}$

\footnotetext{
${ }^{12}$ The CRA is an information seller and monitor in one; it is a financial intermediary that does not provide funding. See, for example, Allen (1990), for a model on the incentive compatibility of information sellers.

${ }^{13}$ More generally, it can be shown that increasing the risk via a mean-preserving spread worsens the credit rating, and therefore increases the differential between the funding costs attached to this rating and the good (safe) rating.
} 
These issues manifest themselves by affecting the funding cost differential between the risky and safe project choices. That is, $F^{R}-F^{S}$ increases as $\beta$ increases and as $\gamma$ falls. This result is consistent with the empirical observation that the funding cost differential between different rating classes goes up and down over time. It is particularly high in uncertain times, if we define uncertain times as periods with increased moral hazard. With respect to the state of the development of the market (i.e., the amount of noise as inversely measured by $\beta$ ), our model points to an elevated impact of ratings on funding costs in more well-developed (less noisy) financial markets.

With respect to the third friction, the only coordination of investor beliefs that exists in the model is that among the institutionally-constrained $\alpha$ investors. Obviously, this rigidity may vary in reality. However, real financial markets may also be characterized by some herding behavior of "free" investors. In particular, analysts may play an important role in forming opinions, and effectively play a role in coordinating beliefs as well. It would be reasonable to conjecture that CRAs are most valuable when analyst expectations are divergent. While, strictly speaking, outside of the context of the model, this would suggest that with divergent analyst expectations, credit ratings have the biggest pricing impact. It also suggests some degree of substitutability between the roles CRAs and analysts play. ${ }^{14}$

Divergence in investor beliefs could be interpreted as another manifestation of uncertain times, which could put pressure on the coordination role of the CRA. It is not inconceivable that due to excessive divergence in investors' beliefs, the implicit contract between the CRA and the rated firm cannot be made incentive compatible. So paradoxically, credit ratings may have most added value when analyst beliefs are very divergent, but beliefs that are too divergent may make it impossible for the CRA to focus beliefs sufficiently and resolve the multiple equilibria problem. In that case, credit ratings lose much of their value, thereby causing fragility and multiple equilibria problems to re-emerge in the financial markets. ${ }^{15}$

\footnotetext{
${ }^{14}$ Ederington and Goh (1998) document that both credit rating agencies and stock analysts bring information to the equity market. They also document that the actions of analysts and rating agencies Granger cause each other, suggesting that they play complementary roles as well. That is, while bond downgrades are typically preceded by declining earnings forecasts, actual and forecasted earnings both fall following a bond downgrade.

${ }^{15} \mathrm{It}$ would also be of interest to look at the typical investor base of a firm. The presence of ratings-dependent institutional investors is central to our "story". While endogenous, our work is most relevant for firms that attract these institutional investors.
} 
CRAs thus play a delicate role; if they manage to do their job, they are most valuable in uncertain times. However, it is precisely in those times that the coordinating role of ratings may break down. ${ }^{16}$

\section{Existing Evidence and New Empirical Predictions}

\subsection{Existing Empirical Evidence}

An interpretation of the existing empirical evidence has previously provided a rather skeptical view towards the predictive power of rating agencies, inducing some to question whether ratings have any value. ${ }^{17}$ For example, Brealey and Myers (2000) claim that "Firms and governments, having noticed the link between bond ratings and yields, worry that a reduction in rating will result in higher interest charges. They almost certainly exaggerate the influence of the ratings agencies, who are as much following investor opinion as leading it." In contrast to such claims, we believe that a careful reading of the existing empirical evidence in light of our theory gives some value to ratings.

Early empirical studies of credit ratings, such as West (1973), Liu and Thakor (1984) and Ederington, Yawitz, and Roberts $(1984,1987)$, focus primarily on ratings as an explanatory variable for cross-sectional differences in yield spreads. Not surprisingly, ratings are found to correlate with observed yield spreads. This observation, however, was to be expected: ratings and credit risk are obviously related. More interestingly, later studies seek to discover the empirical impact of rating changes on security prices. The pervasive finding in these studies - including Weinstein (1977), Ederington and Yawitz (1987), Cornell, Landsman, and Shapiro (1989), Hand, Holthausen, and Leftwich (1992) and Goh and Ederington (1993) - is that there is a significant and negative stock

\footnotetext{
${ }^{16}$ The incentive compatibility of the implicit contract may also depend on the importance firms place on having access to the financial market. If the firm has no need for new funding and its existing debt is unlikely to be repriced soon, incentive compatibility might be difficult to establish.

${ }^{17}$ Partnoy (1999) argues that while rating agencies are taken seriously in the market (in particular, a lower rating can have serious repercussions), this attention is unwarranted. He argues that credit ratings introduce sunspots; ratings lack information content, and only have value because investors choose to have them affect their beliefs. Essentially, investors (privately) conjecture that others will let ratings affect their beliefs, and if everyone behaves as such, ratings will actually alter beliefs. He favors a "new" rating system that relies on market-observed credit spreads.
} 
price reaction to bond downgrades, but there is no significant reaction to upgrades.

We believe that this evidence is consistent with the rationale we have offered for credit rating agencies. Specifically, the implicit contracting that is at the core of our theory is mostly relevant in situations where the CRA and firm strike agreements that should prevent (further) downgrades. In other words, the role CRAs play in practice would make a downgrade a truly informative event as it implies that the firm has not complied with the implicit contract during the "on watch" period.

In related empirical work, Kliger and Sarig (2000) further focus on the causality between stock price movements and rating downgrades. In particular, they design a test that separates ratings changes from potential (simultaneous) changes in credit standing, and thus seek to resolve the uncertainty about the causality. Kliger and Sarig (2000) focus on a change in reported credit ratings categories. This change in "methodology" where a finer partitioning was introduced allows them to exclusively focus on the informational content of the rating change. ${ }^{18}$ Their main result is that (changes in) credit ratings have no statistically significant impact on total firm value, but do have an effect on the value of outstanding debt with an opposite effect on equity value. In practice, a higher rating has a positive impact on the value of the debt, but has a negative impact on the value of equity. For a lower rating, the opposite effects are observed.

What this empirical finding suggests is that the information content of credit ratings is primarily linked to (assessing) risk, with only a secondary or negligible informational content for total firm value. These findings are also consistent with our story. The interpretation would be that the switches between equilibria in our analysis are largely about the level of risk. What this means is that the overall price impact is limited, as credit rating changes lead to redistributions of wealth among the financiers, consistent with Kliger and Sarig's (2000) empirical findings.

\subsection{Empirical Predictions}

As argued above, the theory that we have developed in this paper is consistent with the existing empirical evidence. However, there are several additional and empirically-testable predictions that

\footnotetext{
${ }^{18}$ Kliger and Sarig (2000) focus on the April 26, 1982 introduction by Moody's of a finer rating partition. This event applied to the whole universe of issuers, and could effectively imply a downgrading when put into a low partition, or an upgrading when put into a relatively high one.
} 
can be drawn from the model. These predictions follow from the Corollary to Theorem 3 and the discussion surround this Corollary. In particular, empirical predictions follow from the three frictions discussed in Section 3.3. That is, the level of noise ("presence of lemons"), the severity of moral hazard, and the divergence of beliefs among investors. All affect the increase in funding cost associated with a drop in the rating from the safe to the risky level. Empirical proxies for each of these three factors can be readily identified. Noise could be proxied by some variable measuring the state of development of the financial market. The moral hazard problem depends on the severity of asset substitution problems in a particular industry. This may well be industry dependent, and most severe in industries where large amounts of risk shifting is possible. The irreversibility of investments in a particular industry, and/or the firm's access to liquidity, could be reasonable proxies here. The divergence in beliefs can be proxied by the divergence in analyst earnings forecasts.

\section{Implications and Extensions of the Model}

In this section, we explore several additional implications of our analysis of credit ratings. These include the corporate perception that funding costs are discrete, the predictability of firm behavior, and the benefits of more transparent firms.

\subsection{Funding Cost Discreteness}

Our analysis helps explain discreteness in funding cost. That is, why firms in practice do not view their funding costs as being continuous. The presence of a multiple equilibria problem - and potential switching between equilibria - could introduce discreteness in a firm's funding cost. More specifically, a rating change in our model can change the firm's choice of risk level, and thereby induce a discrete change in the risk profile, and hence funding cost. The more fundamental lesson is that credit ratings guide investor beliefs, and that changes in ratings can lead to drastic revisions in these beliefs. ${ }^{19}$

\footnotetext{
${ }^{19}$ Lizzeri (1999) analyzes the precision of the information communicated by intermediaries. He shows that providing only yes/no type information (e.g., has the minimum standard been met, yes or no?) can be an optimal strategy.
} 


\subsection{Credit Rating Agencies, Fragility and Rumors}

Important in our theory are the implicit contracts between firms and credit ratings agencies. We could say that credit ratings substitute for other explicit forms of monitoring, and actually could make firm behavior more predictable. The idea is that since the credit rating agency examines and possibly controls the firm's choice of risk level, other market participants may rationally reduce monitoring efforts and hence become less responsive to interim signals regarding the quality of the claims they hold. Such dependence on credit ratings and reluctance to react to every observable signal of firm quality could help reduce the fragility of equilibria. ${ }^{20}$

In our model, credit ratings provide an economically meaningful role by fixing an equilibrium when multiple equilibria could otherwise obtain. Observe that in the region where multiple equilibria are possible, market rumors could have a serious impact on firm risk choices as investors try to anticipate firm behavior. In this sense, credit ratings may provide some stability by fixing the equilibrium, implying that market rumors will have a diminished impact on firm behavior. The credit rating agency's implicit contracting feature makes the environment of the firm more predictable and facilitates access to financial markets. Rumors are consequently more contained.

Similarly, a firm with a strong reputation may also be less susceptible to the volatility (fragility) imposed by market rumors as good behavior is anticipated from firms with strong reputations. Hence, credit ratings and firm reputation can have complementary effects in resolving the multiple equilibria problem. When multiple equilibria are possible, credit ratings can fix the desired equilibrium if a sufficient proportion of institutional investors are present. As we saw in the Corollary to Theorem 2, this threshold level of institutional $\left(\alpha^{*}\right)$ investors above which the good firm always plays the safe equilibrium is strictly decreasing in the prior belief $\beta$ that the firm is good. Applying

This type of discrete communication of information (as is common in credit ratings) can also possibly create a discrete price impact.

${ }^{20}$ Gale (1993) builds a model of banks that acquire information about borrowers and develop these relationships over time. However, if a bank were to fail, good borrowers that used this bank are forced to go into the market for a new bank. If there are limits on the aggregate amount of information processing that can be carried out, good borrowers face a lemons problem. Congestion of the information system may lead to market failure. Our model, while not applied directly to banks, purports that credit ratings may help ameliorate such fragility by inducing a substantial proportion of the providers of capital to ignore interim signals that arise. In a recent paper, Da Rin and Hellmann (2001) argue that the most important role served by banks has been as coordinating agents that help the economy achieve the Pareto dominant equilibrium when there are multiple equilibria. In their setting, banks must be sufficiently large to both service a critical mass of firms and possess sufficient market power to profit from this. 
our model to a dynamic setting, the prior belief $(\beta)$ could naturally be interpreted as the posterior belief about firm quality, or its reputation. A stronger reputation implies that a lower threshold level of institutional presence is necessary for credit ratings to serve as focal points and resolve the multiple equilibria problem. ${ }^{21}$

\subsection{Implications for Focus of Firms}

The focal point story necessitates a responsive organization. That is, the threat of a change in the credit rating (as dictated by the implicit contract) should lead to a change in behavior or to a particular action by the company. But this responsiveness is not automatic and may depend on the organizational structure of the firm. To see this, first consider a multi-divisional firm. In this type of organization, the impact of a credit rating change, or more generally a change in funding cost, is diluted at the divisional level. In some sense, divisions free-ride on one another, and see their choices only partially reflected in the firm's cost of capital. This would dilute the impact of credit ratings, unless internal cost of capital allocation systems, such as an EVA (or RAROC) based system, reestablish the link between the division's behavior and its true (divisional) cost of capital. Alternatively, a very centralized firm, where decisions are made at the top, could mitigate these concerns. But this type of resolution seems at odds with the perceived importance of decentralized decision making. ${ }^{22}$ In the end, however, focus might be important for the effectiveness of credit ratings as a coordinating device or focal point.

\section{Conclusion}

Credit ratings are one of the most puzzling features of today's financial markets. Their importance is evident from the behavior of market participants, however, academic researchers have generally been skeptical about their importance. In this paper, we have argued that researchers have failed

\footnotetext{
${ }^{21}$ Disclosure could play a role as well. In the absence of disclosure, the volatility in the market may prohibit the CRA from playing its coordination role. That is, the CRA's ability to focus beliefs may require a minimum level of disclosure in the market. Along these lines, disclosure may also substitute for credit ratings (e.g., with perfect disclosure, credit ratings might be superfluous). Also the corporate governance structure could play a role. In the Anglo-Saxon, market-dependent system (i.e., hands-off), ratings could be more important than in the relationshiporiented, Continental-European model.

${ }^{22}$ See Harris and Raviv (1998) for a recent model of intrafirm decisionmaking.
} 
to understand the role credit rating agencies play and have not adequately appreciated the manner in which credit ratings come about. In particular, we have shown that credit ratings could play a key role as "focal points" once institutional rigidities are considered.

The analysis shows that credit ratings can coordinate investors' beliefs. Together with the implicit contract and monitoring relationship between credit rating agency and firm, ratings have a real impact. The analysis produces several empirically-testable predictions that could be taken to the data, potentially adding to our understanding of the actual credit rating process. 


\section{Appendix}

\subsection{Proof of Lemma 1}

In our model, we assume that firm type is not known a priori. The commonly-held prior belief that a firm is good is $\beta$, and is a lemon with probability $1-\beta$. Lemon firms have access to the risky project only, whereas good firms have access to both the safe and the risky project. Consequently, there are two relevant funding costs to consider. In the first case, the market expects the good firm to choose the safe project, while in the second case, it expects the good firm to choose the risky project. We derive the funding costs for each case below.

Good Firm Chooses Safe Project If investors anticipate that the good firm chooses the safe $(S)$ project, they will lend $I$ and require a repayment of $F^{S}$. Risk-neutral investors require that $E\left[F^{S}\right]=I$. Hence, $F^{S}$ is the solution to

$$
\beta F^{S}+[1-\beta] \gamma F^{S}=I
$$

The required debt repayment when investors anticipate that the safe project will be chosen is

$$
F^{S}=\frac{I}{\beta+[1-\beta] \gamma}
$$

Good Firm Chooses Risky Project If investors alternatively anticipate that the good firm will choose the risky project, they will lend $I$ and require a repayment of $F^{R}$. Again, risk neutral investors require that $E\left[F^{R}\right]=I$, and $F^{R}$ is the solution to

$$
E\left[F^{R}\right]=\beta \gamma F^{R}+[1-\beta] \gamma F^{R}=I .
$$

Since the good firm and the lemon are identical when the good firm chooses the risky project, the prior belief over firm quality is irrelevant and

$$
F^{R}=\frac{I}{\gamma}
$$

Lastly, it is easy to observe that $F^{R}=\frac{I}{\gamma}>\frac{I}{\beta+[1-\beta] \gamma}=F^{S}$. 


\subsection{Proof of Theorem 1}

We can establish the critical prior belief over firm quality $(\underline{\beta})$ as the prior $\beta$ such that the firm is indifferent between choosing the safe and risky project when investors anticipate that the safe project is chosen. Moreover, given that the funding cost when investors anticipate the safe project to be chosen $\left(F^{S}\right)$ is strictly decreasing in $\beta$, for all $\beta<\underline{\beta}$, the good firm would always prefer the risky project independent of investor beliefs over investment choice.

With uncertainty over firm quality, the good firm faces a funding cost of $F^{S}$ when the market expects it to choose the safe project. If the good firm chooses the safe project when facing financing costs of $F^{S}$, in expectation it receives

$$
X_{S}-F^{S}=X_{S}-\frac{I}{\beta+[1-\beta] \gamma} .
$$

Alternatively, if it chooses the risky project when facing such financing costs, it receives in expectation

$$
\gamma\left[X_{R}-F^{S}\right]=\gamma\left[X_{R}-\frac{I}{\beta+[1-\beta] \gamma}\right]
$$

Hence, $\underline{\beta}$ is the value of $\beta$ that solves

$$
X_{S}-\frac{I}{\beta+[1-\beta] \gamma}=\gamma\left[X_{R}-\frac{I}{\beta+[1-\beta] \gamma}\right],
$$

with it solution given by

$$
\underline{\beta}=\frac{I}{\left[X_{S}-\gamma X_{R}\right]}-\frac{\gamma}{[1-\gamma]}
$$

Now observe that if $\beta=\underline{\beta}$ and the market expects the risky project to be taken, the good firm will strictly prefer the risky project. The reason is as follows. If investors instead anticipate that risky project will be chosen, the good firm's expected value upon choosing the safe project is $X_{S}-F^{R}$, and that upon choosing the risky project is $\gamma\left[X_{R}-F^{R}\right]$. We can compare these payoffs to the left and right hand sides of (8), respectively. Relative to the case where investors anticipated the safe project choice, the incremental value loss of choosing the safe project now when facing funding costs of $F^{R}$ is $-\left[F^{S}-F^{R}\right]<0$, while that of choosing the risky project is $-\gamma\left[F^{S}-F^{R}\right]>-\left[F^{S}-F^{R}\right]$. Thus, when investors anticipate the risky project choice at $\beta=\underline{\beta}$, the firm will strictly prefer the risky project. 
A similar argument verifies that the firm strictly prefers to invest in the safe project if this is anticipated by the market for all $\beta>\underline{\beta}$. Now, to insure that multiple equilibria can obtain when $\beta \geq \underline{\beta}$, it must also be the case that the good firm will optimally choose the risky project if investors anticipate this choice. Thus, we must impose the following parametric condition on $\gamma$. The probability that the risky project generates a positive payoff $(\gamma)$ is such that the good firm strictly prefers to choose the risky project when facing funding costs of $F^{R}=\frac{I}{\gamma}$. This condition states that $\gamma$ must be such that the following holds:

$$
\gamma\left[X_{R}-F^{R}\right]>\gamma X_{S}-F^{R}
$$

This can be simplified to

$$
\gamma>\gamma^{*} \equiv \frac{I+\sqrt{I^{2}+4 I\left[X_{R}-X_{S}\right]}}{2\left[X_{R}-X_{S}\right]} .
$$

We assume that $\gamma>\gamma^{*}$ for the remainder of the paper.

In summary, if $\beta<\underline{\beta}$, the good firm chooses the risky project independent of investor beliefs over project choice. For $\beta \geq \underline{\beta}$, the good firm optimally chooses whichever project is anticipated by investors.

\subsection{Proof of Theorem 2}

Observe that for the good firm to prefer the safe project when facing funding costs of $F^{\alpha}$, it must be the case that

$$
X_{S}-F^{\alpha}>\gamma\left[X_{R}-F^{\alpha}\right]
$$

It is obvious that while both the left and right hand sides are decreasing in $F^{\alpha}$, the left hand side decreases at a faster rate. This can be seen most clearly by comparing the two extreme cases of having no investors playing the safe equilibrium $(\alpha=0)$ in the debt market to having only investors playing the safe equilibrium $(\alpha=1)$. When $\alpha=0$, total funding costs are given by $F^{\alpha}=\alpha F^{S}+[1-\alpha] F^{R}=\left[0 \times F^{S}\right]+\left[1 \times F^{R}\right]=F^{R}$. Since all investors anticipate the risky project choice, the good firm confirms this conjecture in equilibrium and optimally chooses the risky project since (4) exceeds (5) for funding costs of $F^{\alpha}=F^{R}$. The opposite result obtains if 
$\alpha=1$. Here, total funding costs are $F^{\alpha}=\alpha F^{S}+[1-\alpha] F^{R}=\left[1 \times F^{S}\right]+\left[0 \times F^{R}\right]=F^{S}$ and the good firm optimally invests in the safe project since (5) now exceeds (4).

Thus, for any given $\beta$, there exists a critical proportion of investors, $\alpha^{*}$, who believe that the safe project will be chosen such that for $\alpha>\alpha^{*}$, the good firm always chooses the safe project. Consequently, the remaining $1-\alpha$ investors also rationally anticipate the safe project choice and total funding costs drop to $F^{S}$.

\subsection{Proof of Corollary to Theorem 2}

Recall that $\alpha^{*}$ is the value of $\alpha$ that equates $\gamma\left[X_{R}-F^{\alpha}\right]$ and $X_{S}-F^{\alpha}$, where $F^{\alpha}=\alpha F^{S}+$ $[1-\alpha] F^{R}$. We can solve explicitly for $\alpha^{*}$ as

$$
\alpha^{*}=\frac{F^{R}-\frac{\left[X_{S}-\gamma X_{R}\right]}{[1-\gamma]}}{\left[F^{R}-F^{S}\right]} .
$$

Since $F^{S}$ is the only variable in the expression for $\alpha^{*}$ that is a function of $\beta$, and $\frac{\partial F^{S}}{\partial \beta}<0$, we see directly that $\frac{\partial \alpha^{*}}{\partial \beta}<0$.

\subsection{Proof of Theorem 3}

The proof of this theorem proceeds in six steps.

1. The credit rating agency "announces" the implicit contract with the firm and the $c_{S}$ credit rating.

2. In the financial market, the $\alpha$ investors, conditioning on the $c_{S}$ rating, anticipate that the good firm will choose the safe project.

3. Based on Theorem 2, the total pricing of the debt claim for $\alpha>\alpha^{*}$ is sufficiently low that the good firm optimally chooses the safe project, even if $1-\alpha$ investors anticipate the risky project.

4. Hence, given the firm's equilibrium behavior, the remaining $1-\alpha$ investors now rationally anticipate that the good firm will choose the safe project, and the firm faces financing costs of $F^{S}$. 
5. The firm optimally chooses the safe project.

6. Consequently, the beliefs of the $\alpha$ investors are confirmed in equilibrium, thereby making it optimal for them to condition on credit rating. Moreover, the CRA sees its implicit contract made incentive compatible (observe that the CRA is "benevolent" in the sense that it plays its role whenever it adds value).

\subsection{Proof of Corollary to Theorem 3}

This corollary can be proven by taking the partial derivative of the difference in funding costs, given by

$$
F^{R}-F^{S}=\frac{I}{\gamma}-\frac{I}{\beta+[1-\beta] \gamma},
$$

with respect to $\beta$ and $\gamma$. With respect to $\beta$, we see that

$$
\frac{\partial\left(F^{R}-F^{S}\right)}{\partial \beta}=\frac{I[1-\gamma]}{[\beta+[1-\beta] \gamma]^{2}}>0 .
$$

With respect to $\gamma$, we have

$$
\frac{\partial\left(F^{R}-F^{S}\right)}{\partial \gamma}=\frac{-\beta I[\beta+\gamma[1-\beta][2-\gamma]]}{\gamma^{2}[\beta+[1-\beta] \gamma]^{2}}<0 .
$$




\section{References}

1. Allen, Franklin, 1990, "The Market for Information and the Origin of Financial Intermediation", Journal of Financial Intermediation 1, 3-30.

2. Brealey, Richard, and Stewart Myers, 2000, Principles of Corporate Finance, 6th edition, Irwin McGraw Hill, New York.

3. Cantor, Richard, and Frank Packer, 1997, "Differences in Opinion and Selection Bias in the Credit Rating Industry", Journal of Banking and Finance 21, 1395-1417.

4. Carey, Mark and Mark Hrycay, 2000, "Parameterizing Credit Risk Models With Rating Data", working paper.

5. Cornell, Brad, Wayne Landsman, and Alan Shapiro, 1989, "Cross-sectional Regularities in the Response of Stock Prices to Bond Rating Changes", Journal of Accounting, Auditing and Finance 4, 460-479.

6. Da Rin, Marco, and Thomas Hellmann, 2001, "Banks as Catalysts for Industrialization", working paper, Stanford University.

7. Dallas, George, 1997, "The Role of Ratings in Public and Private Debt Markets", Standard and Poor's document.

8. Diamond, Douglas W., 1984, "Financial Intermediation and Delegated Monitoring", Review of Economic Studies 51, 393-414.

9. Diamond, Douglas W., 1992, "Monitoring and Reputation: The Choice between Bank Loans and Directly Placed Debt", Journal of Political Economy 99, 689-721.

10. Dow, James, and Nathalie Rossiensky, 1999, "The Cost of Debt for a Financial Firm", working paper, Duke University.

11. Ederington, Louis, and J.C. Goh, 1998, "Bond Rating Agencies and Stock Analysts: Who Knows What and When?", Journal of Financial and Quantitative Analysis 33, 569-585.

12. Ederington, Louis, and Jess Yawitz, 1987, "The Bond Rating Process", in Handbook of Financial Markets and Institutions (ed. Ed Altman), 6th edition, John Wiley and Sons, New York.

13. Ederington, Louis, Jess Yawitz, and Brian Roberts, 1984, "The Information Content of Bond Ratings", working paper no. 1323, National Bureau of Economic Research.

14. Ederington, Louis, Jess Yawitz, and Brian Roberts, 1987, "The Information Content of Bond Ratings", Journal of Financial Research 10, 211-226.

15. Gale, Douglas, 1993, "Informational Capacity and Financial Collapse", in Capital Markets and Financial Intermediation (eds. Mayer and Vives), Cambridge University Press, Cambridge, United Kingdom.

16. Gale, Douglas, and Martin Hellwig, 1985, "Incentive-Compatible Debt Contracts: The OnePeriod Problem", Review of Economic Studies 52, 647-663.

17. Goh, Jeremy and Louis Ederington, 1993, "Is a Bond Rating Downgrade Bad News, Good News, or No News for Stockholders?", Journal of Finance 48-5, 2001-2008.

18. Hand, John, Robert Holthausen, and Richard Leftwich, 1992, "The Effect of Bond Rating Agency Announcements on Bond and Stock Prices", Journal of Finance 47, 733-752.

19. Harris, Milton, and Artur Raviv, 1998, "Capital Budgeting and Delegation", Journal of Financial Economics, 50, pp 259-289.

20. International Herald Tribune, 2002, "Enron's Unthinkable Collapse Blindsided all but the Biggest: US Probes Role of Rating Firms", February 9-10, p9. 
21. Kliger, Doron and Oded Sarig, 2000, "The Information Value of Bond Ratings", Journal of Finance 55-6, 2879-2902.

22. Lizzeri, Alessandro, 1999, "Information Revelation and Certification Intermediaries", Rand Journal of Economics 30-2, 214-231.

23. McDaniel, Raymond, 1997, "Ratings at Moody's", Moody's document.

24. Morris, Stephen, 1999, "Political Correctness", Yale University working paper.

25. Nickell, Pamela, William Perraudin, and Simone Varotto, 1999, "Ratings- Versus EquityBased Credit Risk Modelling: An Empirical Analysis", working paper.

26. Partnoy, Frank, 1999, "The Siskel and Ebert of Financial Markets: Two Thumbs Down for the Credit Rating Agencies", Washing University Law Quarterly 77, 619-712.

27. Saunders, Anthony, 1999, Credit Risk Measurement, John Wiley and Sons, New York.

28. Spatt, Chester and Sanjay Srivastava, 1991, "Preplay Communication, Participation Restrictions, and Efficiency in Initial Public Offerings", Review of Financial Studies 4-4, 709-726.

29. Townsend, Robert M., Optimal Contracts and Competitive Markets with Costly State Verification", Journal of Economic Theory 21, 265-293.

30. Weinstein, Mark, 1977, "The Effect of a Rating Change Announcement on Bond Price", Journal of Financial Economics 5-3, 329-350. 


\section{DAVIDSON INSTITUTE WORKING PAPER SERIES - Most Recent Papers}

The entire Working Paper Series may be downloaded free of charge at: www.wdi.bus.umich.edu

CURRENT AS 4/9/02

\begin{tabular}{|c|c|c|}
\hline Publication & Authors & Date \\
\hline No. 457: Credit Ratings as Coordination Mechanisms & $\begin{array}{l}\text { Arnoud W. A. Boot and Todd T. } \\
\text { Milbourn }\end{array}$ & Mar. 2002 \\
\hline $\begin{array}{l}\text { No. 456: Balkan and Mediterranean Candidates for European Union } \\
\text { Membership: The Convergence of their Monetary Policy with that of the } \\
\text { European Central Bank }\end{array}$ & Josef C. Brada and Ali M. Kutan & Apr. 2002 \\
\hline $\begin{array}{l}\text { No. 455: Russian Financial Transition: The Development of Institutions } \\
\text { and Markets for Growth }\end{array}$ & David M. Kemme & Oct. 2001 \\
\hline $\begin{array}{l}\text { No. 454: Does the Market Pay Off? Earnings Inequality and Returns to } \\
\text { Education in Urban China }\end{array}$ & Xiaogang $\mathrm{Wu}$ and $\mathrm{Yu} \mathrm{Xie}$ & Apr. 2002 \\
\hline $\begin{array}{l}\text { No. 453: Entrepreneurs' Access to Private Equity in China: } \\
\text { The Role of Social Capital }\end{array}$ & Bat Batjargal and Mannie M. Liu & Apr. 2002 \\
\hline $\begin{array}{l}\text { No. 452: The Determinants of Privatised Enterprise Performance in } \\
\text { Russia }\end{array}$ & $\begin{array}{l}\text { Alan A. Bevan, Saul Estrin, Boris } \\
\text { Kuznetsov, Mark E. Schaffer, } \\
\text { Manuela Angelucci, Julian } \\
\text { Fennema and Giovanni } \\
\text { Mangiarotti } \\
\end{array}$ & June 2001 \\
\hline $\begin{array}{l}\text { No. 451: Determinants of Financial Distress: What Drives Bankruptcy } \\
\text { in a Transition Economy? The Czech Republic Case }\end{array}$ & Lubomír Lízal & Jan. 2002 \\
\hline No. 450: Corporate Governance and the Global Social Void & Lee A. Tavis & Oct. 2001 \\
\hline $\begin{array}{l}\text { No. 449: Financial Architecture and Economic Performance: } \\
\text { International Evidence }\end{array}$ & Solomon Tadesse & Aug. 2001 \\
\hline $\begin{array}{l}\text { No. 448: Growth Slowdown Under Central Planning: A Model of Poor } \\
\text { Incentives }\end{array}$ & Zuzana Brixiová and Aleš Bulír & Mar. 2002 \\
\hline $\begin{array}{l}\text { No. 447: Disentangling Treatment Effects of Polish Active Labor } \\
\text { Market Policies: Evidence from Matched Samples }\end{array}$ & $\begin{array}{l}\text { Jochen Kluve, Hartmut Lehmann, } \\
\text { and Christoph M. Schmidt }\end{array}$ & Jan. 2002 \\
\hline $\begin{array}{l}\text { No. 446: The Impact of Socialist Imprinting and Search for Knowledge } \\
\text { on Resource Change: An Empirical Study of Firms in Lithuania }\end{array}$ & $\begin{array}{l}\text { Aldas Kriauciunas and Prashant } \\
\text { Kale }\end{array}$ & Mar. 2002 \\
\hline $\begin{array}{l}\text { No. 445: The Costs, Wealth Effects, and Determinants of International } \\
\text { Capital Raising: Evidence from Public Yankee Bonds }\end{array}$ & $\begin{array}{l}\text { Darius P. Miller and John J. } \\
\text { Puthenpurackal }\end{array}$ & Oct. 2001 \\
\hline No. 444: Financial Institutions, Contagious Risks, and Financial Crises & $\begin{array}{l}\text { Haizhou Huang and Chenggang } \\
\mathrm{Xu}\end{array}$ & Nov. 2001 \\
\hline No. 443: Banks as Catalysts for Industrialization & $\begin{array}{l}\text { Marco Da Rin and Thomas } \\
\text { Hellmann }\end{array}$ & Oct. 2001 \\
\hline $\begin{array}{l}\text { No. 442: Bank-Based or Market-Based Financial Systems: Which is } \\
\text { Better? }\end{array}$ & Ross Levine & Feb. 2002 \\
\hline $\begin{array}{l}\text { No. 441: Migration and Regional Adjustment and Asymmetric Shocks } \\
\text { in Transition Economies }\end{array}$ & Jan Fidrmuc & Feb. 2002 \\
\hline $\begin{array}{l}\text { No. 440: Employment and Wages in Enterprises Under Communism } \\
\text { and in Transition: Evidence From Central Europe and Russia }\end{array}$ & $\begin{array}{l}\text { Swati Basu, Saul Estrin, and Jan } \\
\text { Svejnar }\end{array}$ & June 2000 \\
\hline No. 439: Small business in Russia: A Case Study of St. Petersburg & Alessandro Kihlgren & Jan. 2002 \\
\hline $\begin{array}{l}\text { No. 438: Foreign Direct Investment as Technology Transferred: } \\
\text { Some Panel Evidence from the Transition Economies }\end{array}$ & $\begin{array}{l}\text { Nauro F. Campos and Yuko } \\
\text { Kinoshita }\end{array}$ & Jan. 2002 \\
\hline No. 437: Whistleblowing, MNC's and Peace & Terry Morehead Dworkin & Feb. 2002 \\
\hline $\begin{array}{l}\text { No. 436: A Note on Measuring the Unofficial Economy in the Former } \\
\text { Soviet Republics }\end{array}$ & $\begin{array}{l}\text { Michael Alexeev and William } \\
\text { Pyle }\end{array}$ & Sept. 2001 \\
\hline $\begin{array}{l}\text { No. 435: The Ownership School vs. the Management School of State } \\
\text { Enterprise Reform: Evidence from China }\end{array}$ & David D. Li and Changqi Wu & Jan. 2002 \\
\hline $\begin{array}{l}\text { No. 434: The Effect of Ownership and Competitive Pressure on Firm } \\
\text { Performance in Transition Countries: Micro Evidence from Bulgaria, } \\
\text { Romania and Poland. }\end{array}$ & $\begin{array}{l}\text { Manuela Angelucci, Saul Estrin, } \\
\text { Jozef Konings, and Zbigniew } \\
\text { Zolkiewski }\end{array}$ & Jan. 2002 \\
\hline
\end{tabular}

